\section{Current search for the Commercial Development of Pawpaw [Asimina triloba (L.) Dunal]}

The pawpaw has been prized for its delicious, custard-like fruit since before the arrival of the first European settlers to North America. It is the largest fruit native to the United States (Darrow, 1975) and is native throughout the country east of the Great Plains (Callaway, 1990). It is a member of the tropical family Annonaceae, which includes the custard apple (Annona reticulate L.), cherimoya ( $A$. cherimola Mill.), sweet-sop (A. squamosa L.), and sour-sop (A. muricata L.). Pawpaw's unusual maroon flowers appear from March to May. Mature fruit may be found beginning in August and continuing well into October.

\section{Horticulture}

Culture. Essentially no scientific work has been done on cultural requirements of pawpaws. Because of the difficulty with which they are transplanted, plants are best started as seedlings in deep containers and grown to a height of 0.6 to $0.9 \mathrm{~m}$ before transplanting to the field. Seedlings should be protected from direct sunlight for the first year of growth. Afterward, plants should be placed in full sun, as fruit production is best under these conditions (Willson and Schemske, 1980). The limited cultural information available has been summarized by Callaway (1993).

Pests. Diseases include flyspeck (Zygophiala jamaicensis Mason) and a leaf spot caused by a complex of pathogens [Mycocentrospora asiminae (Ellis et Kellerm.) Leighton, Rhopaloconidium asimitrae (Ellis et Morg.) Petr., and Phyllosticta asiminae Ellis et Kellerm.] (Nasu and Kunoh, 1987; Peterson, 1991). None of these diseases cause significant damage to the fruit. Insect pests include two leaf feeders, Eurytides marcellus Cramer and Omphalocera

Received for publication 2 Dec. 1991. Accepted for publication 27 Dec. 1991. Financial support during manuscript preparation was provided by U.S. Dept. of Agriculture/Cooperative State Research Service Agreement no. KYX-10-91-17P to Kentucky State Univ. and is gratefully acknowledged. The cost of publishing this paper was defrayed in part by the payment of page charges. Under postal regulations, this paper therefore must he hereby marked advertisement solely to indicate this fact.

Front Cover Pawpaw fruit (photograph by Michel Istaphenous). Back Cover: (clockwise from top left) Pawpaw trees displaying fall color (photograph by Dorothy Callaway); pawpaw blossoms (photograph by Neal Peterson); fruit clusters on 'Wilson' pawpaw (photograph by Joe Hickman); variation of fruit among accessions (photograph by Dorothy Callaway). munroei Martin (Damman, 1986), and one peduncle borer, Talponia plummeriana Busck (Allard, 1955), that may cause serious flower loss in some years. A number of vertebrates, such as foxes, opossums, and squirrels, are known to eat the fruit.

Propagation. Seed should not be allowed to dry out before planting. Small quantities should be placed in polyethylene bags containing damp sphagnum moss. Stratification at 2 to $4 \mathrm{C}$ for 60 to 100 days is recommended (U.S. Dept. of Agriculture, 1948). Rate of germination is improved by bottom heat (27 to 30C) and shading (Callaway, 1993; Evert and Payne, 1991; Peterson, 1991). The most reliable method of vegetative propagation is chip budding (unpublished data). Root cuttings have also been successful (U.S. Dept. of Agriculture, 1948). Tissue and softwood propagation methods have not been satisfactorily developed.

Varieties. Compilations of information on past and present varieties have appeared in reports by Callaway $(1990,1993)$ and Peterson (1991). Much of the information available on varieties is subjective and of questionable value. Many "varieties" are trees that have been named by their owners and reported in the literature of various fruit-grower societies. However, until properly conducted variety trials have been carried out, these are the best sources of information available. Of the 68 varieties listed by Callaway (1993), commercial suppliers are known for 19. However, only 'Sunflower' is listed by more than two nurseries; it is listed by six. Eight are listed by two nurseries and 10 by only one. 'Davis', 'Overleese', and' Sunflower' are probably the most widely grown varieties. 'Overleese' and' Sunflower' are generally considered to be among the best varieties currently available. 'Overleese' bears fruit weighing $\approx 350 \mathrm{~g}$ and ripens about the first week of October in Michigan. It was selected from the wild around 1950 in Rushville, Ind. Fruit of 'Sunflower' are somewhat smaller, weighing $-250 \mathrm{~g}$ and ripening at about the same time as 'Overleese' in Michigan. 'Sunflower' originated in Chanute, Kan.

\section{Use and prospects}

Currently, pawpaws are primarily consumed as fresh fruit. They may also be processed into ice creams, juices, and other products, as are their Annona relatives. In addition Lafayette, Ind., have found that the vegetative parts of the pawpaw plant contain compounds that exhibit highly effective pesticidal and anticancer properties (Alkofahi et al., 1989; to food uses, scientists at Purdue Univ., West
Rupprecht et al., 1986, 1990). Although pawpaw is native to the United States, its commercialization is more advanced in other countries, such as Japan and Italy. I am aware of only one commercial planting in the United States and these plants are still too small to bear fruit. However, this situation seems to be changing. Pawpaw plants have been selling briskly in the nursery trade, particularly named varieties. None of the nurseries selling pawpaw varieties have been able to meet the demand within the last 2 years. Although adequate assessment of market demand is quite difficult for new crops, these examples indicate that the prospects for successful commercialization of this fruit appear good.

\section{Pawpaw research at Kentucky State Univ.}

Although Kentucky State Univ. (KSU) is one of the 1890 land-grant institutions, research in horticulture first began in June 1990. From its inception, the horticulture program has placed a priority on the development of pawpaw as a commercial crop. Shortly after arriving at KSU, I initiated a nationwide contest with two goals in mind: 1) collection of germplasm and 2) increasing the public's awareness of pawpaws (Callaway, 1991). This contest was based on one conducted in 1916 by the American Genetic Association to identify superior pawpaws from the wild (American Genetic Assn., 1917). The 1990 contest resulted in more than 430 fruit entries from 75 persons in 15 states. Several nurseries have expressed interest in marketing contest entries. One that is being marketed, 'Wells', immediately sold out for 1992 and has awaiting list of buyers for 1993. This variety was the winner of the 1990 contest, weighing $>400 \mathrm{~g}$. It was discovered growing wild on the property of David Wells of Salem, Ind. Public interest in pawpaws was also stimulated by the contest. Hundreds of letters have been received from 40 states and seven foreign countries. Newspaper, magazine, and television coverage continues 1 year after the contest, improving public awareness for pawpaws. In addition to germplasm collection, research projects are continuing on improved methods of propagation, the genetics of commercially important traits (e.g., yield, fruit size, and quality), variety and elite line yield testing, and variety development.

In Jan. 1990, KSU hosted the first meeting of pawpaw researchers. Scientists and institution representatives attended from Georgia; Arkansas; Washington, D. C.; Indiana; Maryland; and Kentucky. This meeting provided a forum for the exchange of information on pawpaw research. Because of the recent initiation of pawpaw research projects at several institutions, coordination of research efforts early in the development of this crop is possible. The establishment of much-needed regional test sites and coordinated data collection was discussed. The first regional variety test site will be established at KSU in Spring 1992.

(continued on inside back cover) 
(continued from inside front cover)

\section{Research needs}

Pawpaw research is in its infancy. Several research needs have been identified (Callaway, 1990, 1993), including germplasm collection, improved methods of vegetative propagation, pollination biology, genetics of commercially important traits, variety trials, cultural information, and fruit processing and storage.

\section{Literature Cited}

Alkofahi, A., J.K. Rupprecht, J.E. Anderson, J.L. McLaughlin, K.L. Mikolajczak, and B.A. Scott. 1989. Search for new pesticides from higher plants, p. 25-43. In: J.T. Arnason, B.J.R Philogene, and P. Morand (eds.). Amer. Chem. Soc. Sym. Ser. 2:387.

Allard, H.A. 1955. The native pawpaw. Atlantic Naturalist 10:197-203.

American Genetic Association. 1917. The best papaws. J. Hered. 8:21-33.

Callaway, M.B. 1990. The pawpaw (Asimina triloba). Kentucky State Univ. Publ. CRSHORT1-901T.
Callaway, M.B. 1991. Germplasm collection using public contests-The Asimina triloba example. ASHS 1990 Annu. Mtg., University Park, Pa., Prog. \& Abstr. p. 722.

Callaway, M.B. 1993. Pawpaw (Asimina triloba), a "tropical" fruit for temperate climates. In: J. Janick and J. Simon (eds.). New crops: Exploration, research, commercialization. Timber Press, Portland, Ore. (In press.)

Damman, A.J. 1986. Facultative interactions between two lepidopteran herbivores of Asimina. Oecologia 78:214-219.

Darrow, G.M. 1975. Minor temperate fruits, p. 276-277. In: J. Janick and J.N. Moore (eds.). Advances in fruit breeding. Purdue Univ. Press, West Lafayette, Ind.

Evert, D.R. and J.A. Payne. 1991. Germination of Asimina triloba and A. parviflora. ASHS 1990 Annu. Mtg., University Park, Pa., Prog. \& Abstr. p. 777.

Nasu, H. and H. Kunoh. 1987. Scanning electron microscopy of flyspeck of apple, pear, Japanese persimmon, plum, Chinese quince, and pawpaw, Plant Dis. 71:361-364.

Peterson, R.N. 1991. Pawpaw (Asimina), p, 567600. In: J.N. Moore and J.R. Ballington (eds.). Genetic resources of temperate fruit and nut crops. Acts Hort. 290-XII. Intl. Soc. Hort. Sci., Wageningen, The Netherlands.

Rupprecht, J.K., C.-J. Chang, J.M. Cassady, and J.L. McLaughlin. 1986. Asimicin, a new cytotoxic and pesticidal acetogenin from the pawpaw, Asimina triloba (Annonaceae). Heterocycles 24:1197-1201.

Rupprecht, J. K., Y.-H. Hui, and J.L. McLaughlin. 1990. Annonaceous acetogenins: A review. J. Natural Products 53:237-278.

U.S. Dept. of Agriculture. 1948. Asimina triloba (L.) Dunal, pawpaw. Woody-plant seed manual. U.S. Dept. Agr., Washington, D.C. Misc. Publ. 654. p. 92.

Willson, M.F. and D.W. Schemske. 1980. Pollinator limitation, fruit production, and floral display in pawpaw (Asimina triloba). Bul. Torrey Botanical Club 107:401-408.

M. Brett Callaway Dept. of Plant and Soil Science Kentucky State Univ. Frankfort, KY 40601 and

Dept. of Horticulture Univ. of Kentucky Lexington, KY 40546-0091 